\title{
Geoinformation support of environmental safety while Arctic and Subarctic territories sustainable development
}

\author{
Vyacheslav Burlov, Valery Abramov*, Igor Sikarev, Oleg Shevchuk, and Yaroslav Petrov ${ }^{1}$ \\ Russian State Hydrometeorological University, Voronezhskaya str., 79, 192007 St.-Petersburg, \\ Russia
}

\begin{abstract}
Article considers digital tools development results for geoinformation support of environmental safety while sustainable development of the Arctic and subarctic territories in the era of Industry 4.0 within adaptation to climate change and COVID-19 conditions. The study used methods of decision-making under uncertainty and digital tools of distributed platforms with new concepts of data acquisition and presentation. It is proposed to use open-source digital online platforms for geoinformation support of environmental safety within sustainable development of the Arctic and subarctic territories in the era of Industry 4.0 and simultaneous adaptation to climate change and COVID-19 conditions. There are considered examples of proposed digital platforms using. The results of the research can be used for managerial, scientific, educational and training purposes.
\end{abstract}

\section{Introduction}

Now, the sustainable territories development is implemented mainly within the geographic information management (GIM) paradigm [1-5]. That leads to significant changes in the geoinformation support for Arctic and Subarctic territories sustainable development (ASTSD), which should be implemented in the Industry 4.0 era, when climate change and the COVID-19 pandemic are simultaneously occurring. It should be noted that Industry 4.0 leads to major technological changes in the geoinformation support systems (GISS) and management support systems (MSS) for ASTSD, including the geo-ecological support systems (GESS) [6-13] and natural risk management (NRM) [14-17], which requires the development of new digital technologies and tools. Within the framework of the ASTSD, special attention should be paid to environmental safety (ES) [18-23] and compensatory measures (CM) [24-27].

The study's goal is the digitalization of GESS for ES within ASTSD. In paper, we describe the results of innovative digital tools development of GESS for ES within ASTSD, in the framework of GIM paradigm, including the issues of information collection and processing [28-30] in the context of climate change and the COVID-19.

\footnotetext{
*Corresponding author: val.abramov@mail.ru
} 


\section{Materials and Methods}

While study, we used theory of decision making under uncertainties, Foresight technologies, risk management approach, methods of data bases constructing and webtechnologies. Also, it is used big data technologies [28-30]. From the point of view of GIM, geo-space structured to allocate the interconnected components of the solution space [4]. In research, it is used data bases and tools of geo-information digital online platforms (GIDOPs) EOS, including its Land Viewer (LV) product https://eos.com/landviewer/ and Earth https://earth.nullschool.net/ru/.

\section{Results}

As a result of the study, we put the statement that ASTSD at the present stage should be implemented within paradigm of sustainable development as an interconnected set of large natural and industrial projects (PIP) within a single space-time space and a single adequate geoinformation and management support. Based on research using Foresight technologies, it is proposed to develop a GESS and a MSS for ASTSD with a combined structure for accessing, storing and analyzing information from open geospatial data sources, including archives and web-based operational tools. It is proposed to use geoinformation distributed online platforms (GIDOPs) EOS, including its Land Viewer (LV) product https://eos.com/landviewer/ and Earth https://earth.nullschool.net/ru/ as the main technological solutions to GISS and a MSS for ASTSD.

In fig.1-3, we show the examples of above mentioned GIDOPs usage.

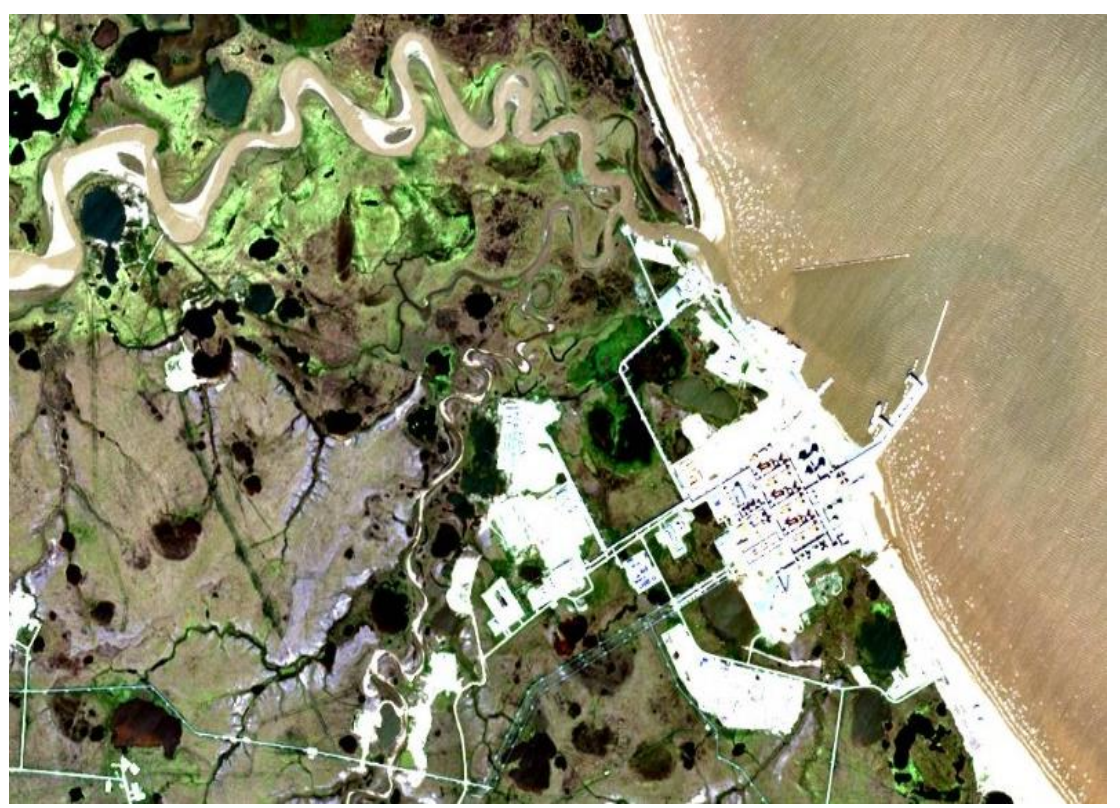

Fig. 1. Territory around liquid natural gas plant (LNGP) at Sabetta, visualized for ES within ASTSD purposes with GIDOP EOS LV Normal Color Application, 21/08/2020, scale $1 \mathrm{~km}$. 


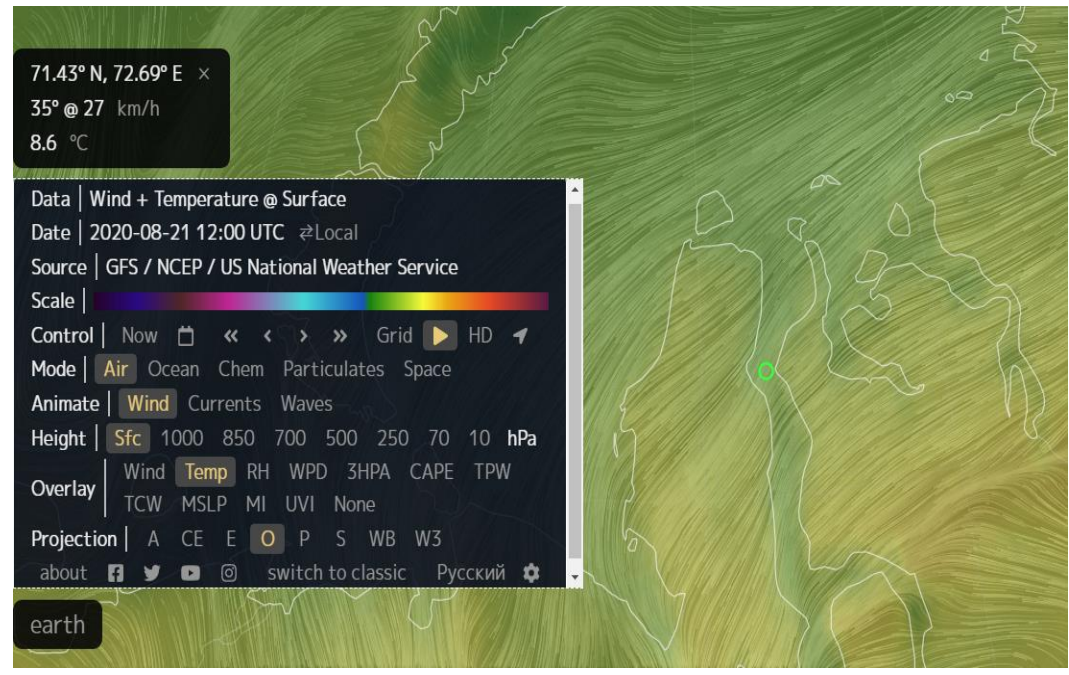

Fig.2. Weather data (wind, air temperature) at Sabetta, visualized for ES within ASTSD purposes with GIDOP Earth on 21/08/2020.

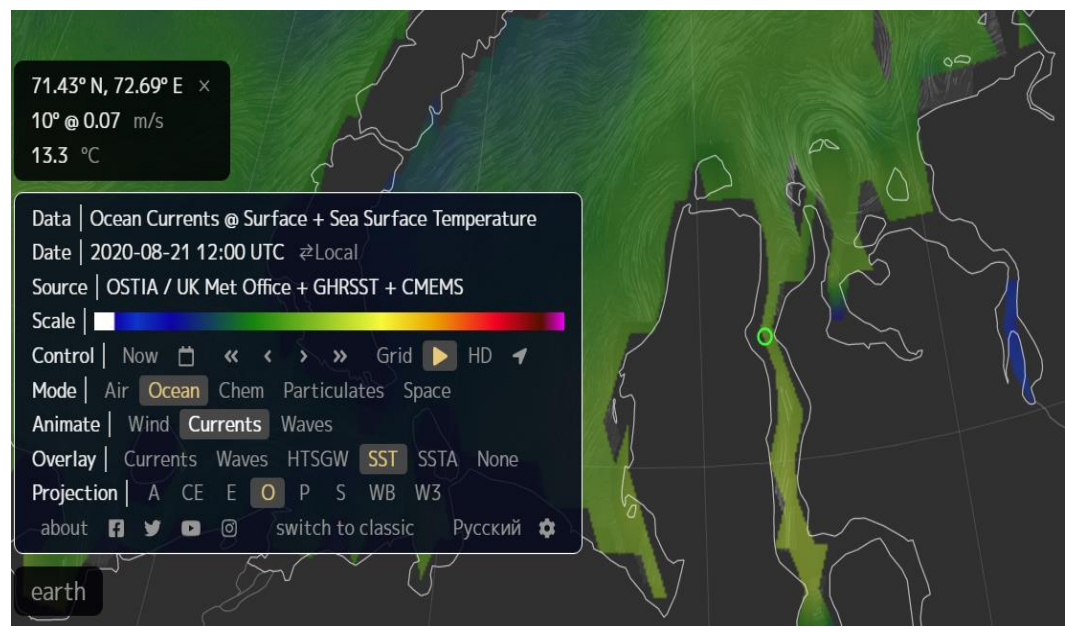

Fig.3. Water data (currents, sea surface temperature) at Sabetta, visualized for ES within ASTSD purposes with GIDOP Earth on 21/08/2020.

As the main result, we propose to use the above-mentioned GIDOPs as the basis for a low-cost GISS and MSS for ES within ASTSD purposes. Note, decoding and discussing the data from figures 1-3 is not the task of this article.

\section{Discussion}

Above proposed low-cost innovative digital tools for ES within ASTSD can be used in educational and training purposes [2]. The essential task of university practical learning in the field of ES within ASTSD will be to teach students the practical aspects of work with GISS tools, which requires a develop d learning base within special geo-information systems (GIS) laboratory. In some cases, real practical work in special GIS laboratory can be undergoes with virtual reality (VR) technologies, that can reduce total cost of learning process. 


\section{Conclusions}

Paper discusses innovative digital tools development for ES within ASTSD, which simultaneously takes into account the impact of the period of Industry 4.0, climate change and the COVID-19 pandemic. In research, there was used theory of decision making under uncertainties, risk management approach, Foresight technologies, methods of data bases constructing, web-technologies and virtual reality tools. As study result, we suggest to use GODOPs Earth and EOS, including its Land Viewer (LV) product, as the main digital tools within GISS and MSS for ES within ASTSD. We recommended to use research results in educational and training purposes, including preparing Master's programs in environment economics, Earth sciences and others areas. The research results have significant scientific novelty and can be useful for government and municipal organizations, independent market players and private investors. In article, all graphical materials are original and produced by authors with data from open sources.

\section{Acknowledgements}

While research, we use platform https://www.researchgate.net/profile/Valery_Abramov2/ for preliminary discussion and data exchange.

\section{References}

1. A. Ershova, Ya. Matveev, M. Shilin, N. Popov, O. Mandryka, A. Chusov, E3S Web of Conferences, 110, 0102 (2019)

2. S. Lukyanov, N. Popov, I. Sikarev, E. Rumyantseva, O. Petrieva, E3S Web Conf., 258, 01004 (2021)

3. V. A. Bolshakov, T.V Vekshina, V. M. Abramov, V. N., Veretennikov, E. M. Korinets, International Multidisciplinary Scientific GeoConference Surveying Geology and Mining Ecology Management, SGEM, 19 (2.1), 903 (2019)

4. E. P., Istomin, V.G. Burlov, V. M Abramov, A. G., Sokolov, S. I. Bidenko, 2019 International Multidisciplinary Scientific GeoConference Surveying Geology and Mining Ecology Management, SGEM, 19 (5.3), 139 (2019)

5. G. Gogoberidze, J. Lednova, A. Chusov, M. Shilin, 2018 IEEE/OES Baltic International Symposium, BALTIC 2018, 8634848 (2019)

6. M. Shilin, V. Abramov, A. Chusov, Transportation Research Procedia, 54, 654 (2021)

7. E. S. Andreeva, M. B. Shilin, V. M., Abramov, S. S. Andreev, E. A. Yaily, International Multidisciplinary Scientific GeoConference Surveying Geology and Mining Ecology Management, SGEM, 19 (5.1), 399 (2019)

8. O. N. Mandryka, V. M. Abramov, M. B. Shilin, A. A. Ershova, Y. L. Matveev, A. N. Chusov, N. N. Popov, Proceedings of the 33rd International Business Information Management Association Conference, IBIMA 2019: Education Excellence and Innovation Management through Vision 2020, 7173 (2019)

9. M. Shilin, I. Sikarev, E. Baikov, G. Gogoberidze, O. Petrieva, E3S Web Conf., 258, 01003 (2021)

10. A. Ershova, M. Shilin, V. Abramov, O. Mandryka, A. Chusov, International Multidisci plinary Scientific GeoConference Surveying Geology and Mining Ecology Management, SGEM, 19 (5.2), 347 (2019) 
11. J. Lednova, A. Chusov, M. Shilin, Ocean: Past, Present and Future - 2012 IEEE/OES Baltic International Symposium, BALTIC 2012, 6249169 (2012)

12. J. Lednova, G. Gogoberidze, V. Zhigulsky, M. Shilin, A. Chusov, 14th MEDCOAST Congress on Coastal and Marine Sciences, Engineering, Management and Conservation, MEDCOAST 2019, 1, 161 (2019)

13. J. Lednova, A. Chusov, M. Shilin, M., Proceedings of the 10th Global Congress on ICM: Lessons Learned to Address New Challenges, EMECS 2013 - MEDCOAST 2013 Joint Conference, 2, 1024

14. E. P. Istomin, V. M. Abramov, O. M. Lepeshkin, E. A. Baikov, S. I. Bidenko, Internati onal Multidisciplinary Scientific GeoConference Surveying Geology and Mining Ecology Management, SGEM, 19, 953 (2019)

15. A. Sokolov, V. Abramov, E. Istomin, E. Korinets, V. Bolshakov, T. Vekshina, IOP Conference Series: Materials Science and Engineering, 940(1), 012003 (2020)

16. S.V. Lukyanov, V. M., Abramov, A. S. Averkiev, A. E., Rybalko, Yu. A. Tatarenko N. S. Frolova, O. I. Shevchuk, Proceedings of the 33rd International Business Informat ion Management Association Conference, IBIMA 2019: Education Excellence and Innovation Management through Vision 2020, 7112 (2019)

17. L. N., Karlin, V. M. Abramov, A. A. Ovsiannikov, Oceanology, 49 (3), 327 (2009)

18. A. Ershova, M. Shilin, V. Zhigulsky, A. Chusov, V. Abramov, T. Bagrova, N. Popov, 2018, 2018 IEEE/OES Baltic International Symposium, BALTIC 2018, 8634858 (2018)

19. M. P. Fedorov, M. B. Shilin, Power Technology and Engineering, 44 (2), 117 (2010)

20. V.G. Burlov, V. M., Abramov, T. M. Tatarnikova, IOP Conference Series: Earth and Environmental Science, 666 (5, 9), 052076 (2021)

21. T. Eremina, A. Ershova, G. Martin, M. Shilin, 2018 IEEE/OES Baltic International Symposium, BALTIC 2018, 8634860 (2019)

22. N. Bobylev, A. Chusov, M. Shilin, G. Gogoberidze, A. Ershova, J. Lednova, E3S Web of Conferences, 164, 01010 (2020)

23. Y. S Vasil'ev, V. I. Maslikov, M. B. Shilin, A. N. Chusov, D.V. Molodtsov, T. R. Eremina, A. A. Ershova, Power Technology and Engineering, 53 (3), 314 (2019)

24. S. Kouzov, M. Shilin, A. Chusov, J. Lednova, Measuring and Modeling of Multi-Scale Interactions in the Marine Environment - IEEE/OES Baltic International Symposium 2014, BALTIC 2014, 6887863 (2014)

25. V. Mikheev, M. Shilin, V. Abramov, V. Zhigulsky, A. Chusov, International Multidisciplinary Scientific GeoConference Surveying Geology and Mining Ecology Management, SGEM, 19 (5.2), 701 (2019)

26. S. Kouzov, A. Chusov, J. Lednova, V. Zhigulsky, M. Shilin, A. Ershova, 13th International MEDCOAST Congress on Coastal and Marine Sciences, Engineering, Management and Conservation, MEDCOAST 2017, 1, 257 (2017)

27. G. Gogoberidze, V. Zhigulsky, M. Shilin, A. Ershova, A. Chusov, International Multid isciplinary Scientific GeoConference Surveying Geology and Mining Ecology Management, SGEM, 17 (52), 935 (2017)

28. A. Sokolov, A. Fokicheva, V.Abramov, E. Istomin, E. Goloskvskaya, A. Levina, Proceedings of the 33rd International Business Information Management Association Conference, IBIMA 2019: Education Excellence and Innovation Management through Vision 2020, 8638 (2019) 
29. N. Popov, E. Istomin, A. Popova, V. Abramov, A. Sokolov, A. Levina, Proceedings of the 33rd International Business Information Management Association Conference, IBIMA 2019: Education Excellence and Innovation Management through Vision 2020 2019, 8575 (2019)

30. E. P. Istomin, A. G. Sokolov, V. M. Abramov, V. V. Novikov, E. A. Yaily, Internation al Multidisciplinary Scientific GeoConference Surveying Geology and Mining Ecology Management, SGEM, 19 (2.1), 753 (2019) 